\title{
Cultivation of Native Seaweed Gracilaria domingensis (Rhodophyta) in Southern Brazil
}

\author{
José Pedrassoli Salles, Fernando Scherner, Cristalina Yoshie Yoshimura, Maurício \\ Fanganiello, Zenilda Laurita Bouzon and Paulo Antunes Horta* \\ Laboratório de Ficologia; Departamento de Botânica; Universidade Federal de Santa Catarina; 88010-970; \\ Florianópolis - SC - Brasil
}

\begin{abstract}
The aim of this work was to study the cultivation of Gracilaria domingensis in a mussel farming urbanized area in Santa Catarina, Brazil. Relative growth rate was the parameter used to evaluate the cuttings attachment methods on the cultivation rope, cuttings density, cultivation period and cystocarpic versus unfertile thalli performance. The cultivation was feasible only when protected by net cages due to herbivory. The tie-tie attachment method presented the best results. No differences were observed when comparing the cuttings densities and reproductive phase. Future studies should evaluate the cost-effectiveness of producing the species in net cages and its potential as biofilter.
\end{abstract}

Key words: Gracilaria domingensis, marine aquaculture, seaweed cultivation, cultivation methods

\section{INTRODUCTION}

Gracilaria is among the major edible Rhodophyta seaweeds (Norziah and Ching, 2000). Its cultivation has become an important activity in several parts of the world (Buschmann et al., 1997), being mainly used for agar production (Troell et al., 1997; Marinho-Soriano and Bourret, 2003). However, despite its long coast, Brazil still lacks technology to cultivate native species of Gracilaria and produce insignificant quantities of agar for the domestic market, being dependent on importation (Yoshimura, 2006). The increased demand for agar and alginates combined with the lack of sustainable aquaculture has resulted in over-exploitation of natural seaweed beds in the north-eastern Brazilian coast (Oliveira and
Miranda, 1998). Besides the economic side of seaweed cultivation, it also plays an important role in environmental quality issues, since seaweed cultivation has been demonstrated to improve the water quality of enriched waters (Glenn et al., 1999). On the other hand, the Brazilian marine aquaculture, primarily mussel cultivation, has increased significantly in recent years. The growth in the production scale associated with the increase in effluent discharges in coastal zones may affect the health and marketability of farmed mussels (Bainy et al., 2000), which has a large infrastructure and labor contingent dependent on this activity. During the winter, due to low temperatures and market retraction, much of this production system, infrastructure and work force become idle. In this scenario, seaweed cultivation

*Author for correspondence: pahorta@ccb.ufsc.br 
could have an important potential role by providing extra income to mussel farmers during the winter while improving water quality.

The evaluation of suitable techniques for the target species is an important step before implantation of cultivation systems. Therefore, researching an alternative strategy for the productive system, since marine aquaculture has no tradition on seaweed production in the country, is an important step towards long term sustainability of aquaculture activities in Brazil. The aim of this work was to study an experimental open water vertical cultivation of Gracilaria domingensis in Southern Brazil. The following cultivation aspects were evaluated: cuttings attachment methods on the cultivation rope; cuttings density; cultivation period; and cystocarpic versus unfertile thalli performance.

\section{MATERIAL AND METHODS}

The experiments were conducted in the Northern Bay of Santa Catarina Island at Sambaqui beach (2729'15's; 48³2'24' W), Florianópolis, SC, Brazil, from May, $2^{\text {nd }}$ to July, $14^{\text {th }} 2003$, using the long line system in a mussel farm installed $100 \mathrm{~m}$ from the shore line. The use of vertical ropes was compatible with the mussel culture system and also allowed growth comparisons through a depth gradient. The cuttings were cultivated at depths from 0.2 to $1.1 \mathrm{~m}$. The specimens used on the experiments were collected from Forte beach, in Florianópolis.

Data of daily environmental conditions (air temperature, wind direction and speed, precipitation and cloudiness) for the experimental period were obtained from the National Institute for Meteorology (INMET). The relative growth rate $\left(\mathrm{RGR}, \%\right.$. day $\left.^{-1}\right)$, as proposed by Dawes (1998), was the parameter used to assess the different cultivation aspects:

$\mathrm{RGR}=(((\mathrm{Wf}-\mathrm{Wi}) / \mathrm{Wi}) / \mathrm{t}) * 100$

Where: $\mathrm{Wi}=$ initial fresh weight $(\mathrm{g}), \mathrm{Wf}=$ final fresh weight $(\mathrm{g}), \mathrm{t}=$ cultivation time (days).

The initial and final biomasses free from epiphytes and sediments were recorded for each cutting cultured. In all the experiments, the initial fresh weight of each cutting was approximately $1.0 \mathrm{~g}$. The comparisons of the performance in each experiment were done using two types of RGR.
Potential Relative Growth Rate (P-RGR), determined excluding negative RGRs, and Real Relative Growth Rate (R-RGR), which includes the negative values obtained. For all experiments the handling period was of 7 days, except for the last experiment, which evaluated the one week versus two weeks handling factor.

The first experiment was carried out to evaluate the feasibility of cultivation without cages. Eleven cultivation ropes were prepared tying the cuttings with soft nylon tape (tie-tie method). The spacing interval between the cuttings was $0.1 \mathrm{~m}$ with 10 cuttings tied to each cultivation rope. In this experiment, the cultivation ropes were tied directly to the long line.

The second experiment evaluated the cultivation feasibility inside the cages for macrograzers exclusion. The cages were $1 \mathrm{~m}^{3}$ covered with plastic net $(1 \mathrm{~cm}$ mesh size $)$ and attached to four buoys on each corner. The cages were laterally tied to the long line and the cultivation ropes hung within the cages. Three cages with four ropes hung inside each cage were set up. Since the cultivation without cages showed no feasibility and the one with exclusion cages performed good yields, the use of cages were adopted for all the following experiments.

The third experiment was designed to test for the cuttings attachment methods. The first method used soft nylon tape (tie-tie method) to tie the thalli on the rope. The second method consisted of inserting the thalli between the rope strands. Four cultivation ropes were prepared for each attachment method and the plants were cultured in a density of 10 cuttings/rope. To avoid a significant depth effect against the attachment methods evaluation, the two deepest cuttings were excluded, hence only the eight first cutting were evaluated for attachment methods comparison.

A fourth experiment evaluated the cultivation density. Three different densities were tested: 8,10 and 15 cuttings/cultivation rope and they were tied at approximately $0.15,0.10$ and $0.07 \mathrm{~m}$ from each other, respectively. Three ropes were prepared for each density.

To evaluate the performance of cystocarpic versus unfertile plants, a fifth experiment was carried out by adopting a density of 10 cuttings/rope, considering the relatively low frequency of cystocarpic plants in the sampled population. Three cultivation ropes were prepared for each reproductive form. 
The last experiment evaluated two cultivation periods to assess two handling intervals: one and two weeks. Six ropes were prepared with a density of 15 cuttings/rope. With one week of culture, three ropes were randomly sampled and analyzed. The same procedure was made after the following week.

Values of RGR were evaluated for each experiment. After assessing homogeneity of variances using the Cochran test $(p<0.05)$, oneway or factorial ANOVA was performed to test for significant differences $(\mathrm{p}<0.05)$ comparing RGR under different experimental conditions. Data that presented no homogeneity was added a constant to reflect the negative distribution and then transformed by $\log (\mathrm{x}+1)$. Whenever significant differences were found, the Tukey HDS test was applied for post-hoc comparisons. All the analyses were accomplished using the program Statistica 7.0.

\section{RESULTS}

Average temperature during the experimental period remained relatively stable at about $18{ }^{\circ} \mathrm{C}$. Winds from the North and South quadrants were very frequent and reached speed as high as $13 \mathrm{~m} . \mathrm{s}^{-1}$. Such winds were related to the high water motion observed in the field. The frequency and intensity of rains varied during the period, with a maximum of $68.5 \mathrm{~mm}$ in June. The cloudiness increased from May to July, consequently decreasing the available irradiation (Table 1).

Table 1 - Summary of the environmental factors observed during the experimental period.

\begin{tabular}{lcccc}
\hline & & May & June & July \\
\hline Temperature $\left({ }^{\circ} \mathrm{C}\right)$ & & $19.2(28.4 / 7.3)$ & $18.4(28.6 / 11.2)$ & $18.4(25.9 / 10.8)$ \\
Mean (max./min.) & N quadrant & 40 & 41 & 52 \\
Wind direction (\% days) & S quadrant & 42 & 42 & 33 \\
Wind speed (m.s $\left.{ }^{-1}\right)$ & N quadrant & $2.8(6.5 / 0.5)$ & $2.7(8.0 / 0.3)$ & $2.5(4.6 / 0.8)$ \\
Mean (max./min.) & S quadrant & $2.9(10.5 / 0.4)$ & $4.2(13 / 0.3)$ & $5.6(9.0 / 5.6)$ \\
Precipitation (mm) & & 22.6 & 68.5 & 42.0 \\
Cloudiness (max/min) & & $4.9(10 / 0)$ & $5.7(10 / 0)$ & $6.1(10 / 0)$ \\
\hline
\end{tabular}

Although not quantified, during the whole experimental period, epiphytic filamentous algae were abundant and diverse on the cultivated thalli. Among them, Polysiphonia gorgoniae, Ceramium tenerrimum and Hincksia mitchelli were the most frequent species.
The first experiment presented higher negative RGR values as depth increased $(\mathrm{F}=7.00, \mathrm{p}<0.01)$ (Fig. 1). P-RGR reached up to $4 \% \cdot$ day $^{-1}$ at $0.4 \mathrm{~m}$ depth, whereas in depths higher than $0.8 \mathrm{~m}$, it was as low as zero. The culture where net cages were used presented P-RGRs from 1.5 to $4.6 \%$.day ${ }^{-1}$.

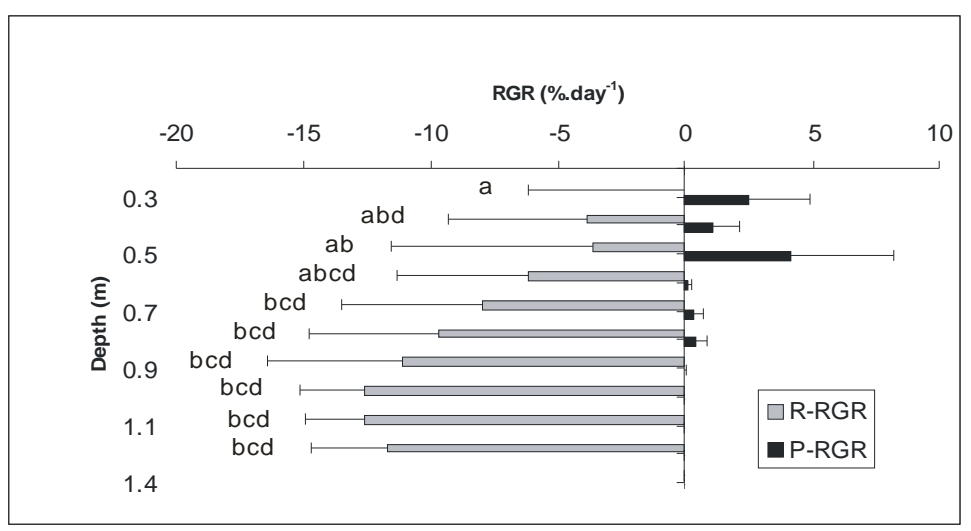

Figure 1 - Average RGR $\left(\% \cdot\right.$ day $\left.^{-1}\right)$ for $G$. domingensis for the experiment performed without net cages, with the cultivations ropes tied directly to the long line, accomplished in May 2003. Letters indicate differences on RGRs according to Tukey HSD ( $\mathrm{p}<0.05)$ (P-RGR Potential Relative Growth Rate; R-RGR = Real Relative Growth Rate; density = 10 cuttings/rope; $\mathrm{n}=11$; bars $=$ st. dev.) 
Negative R-RGR values were observed only for thalli cultivated below $1.0 \mathrm{~m}$ (Fig. 2). No significant differences in RGR values were observed. The tie-tie method showed better RGRs values compared to the inserting method $(\mathrm{F}=4.76$, p<0.05) (Fig. 3).

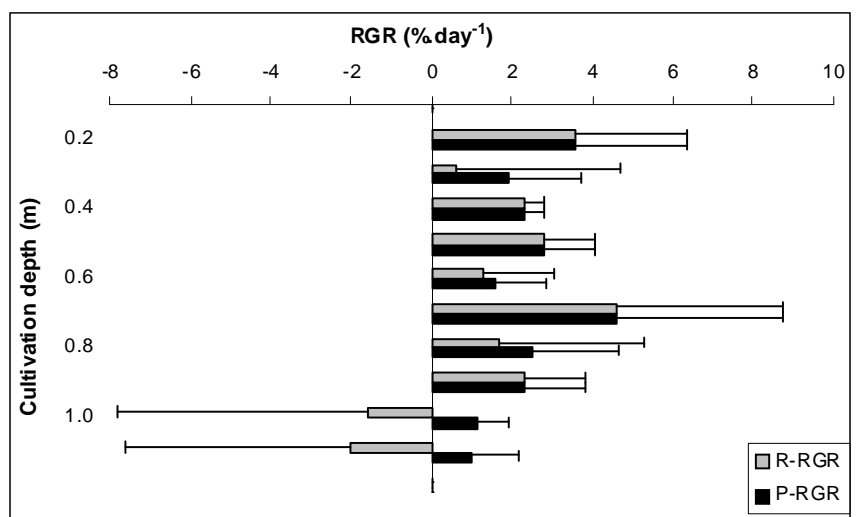

Figure 2 - Average RGR (\%.day $\left.{ }^{-1}\right)$ for G. domingensis cultivated within net cages excluding macrograzers, accomplished in June 2003 (P-RGR = Potential Relative Growth Rate; R-RGR $=$ Real Relative Growth Rate; density $=10$ cuttings/rope; $n=4$; bars $=$ st. dev.).

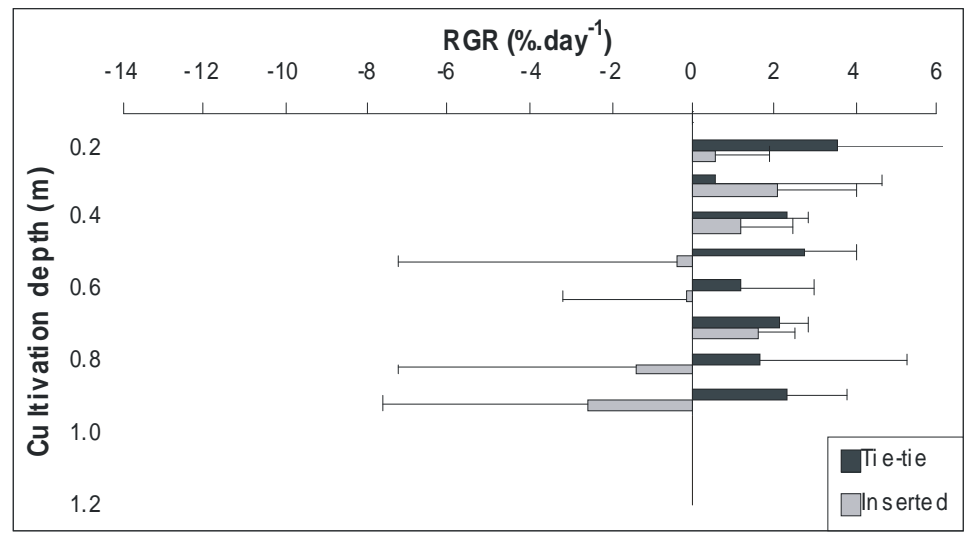

Figure 3 - Average RGR $\left(\% \cdot\right.$ day $\left.^{-1}\right)$ for $G$. domingensis cultivated in net cages comparing two attachment methods: tie-tie and inserting into the strand of the rope, accomplished in June 2003 (where: RGR used = Real Relative Growth Rate; density $=10$ cuttings/rope; $n=4$; bars $=$ st. dev. . .

Cuttings density evaluation presented values ranging from 1.5 to $2.0 \%$. day ${ }^{-1}$ for R-RGR and from 2.1 to $2.7 \%$.day $^{-1}$ for P-RGR (Fig. 4). However, no significant differences were observed. The experiment that evaluated the cultivation period presented no significant differences for RGR, despite the higher R-RGR average found for one-week than for two-weeks of cultivation period (Fig. 5). The two-week period presented high loss of cuttings (one week: four plants lost; two-weeks: 21 plants lost). Differences in growth rates of cystocarpic and unfertile plants were not significant according to ANOVA (Fig. 6). 


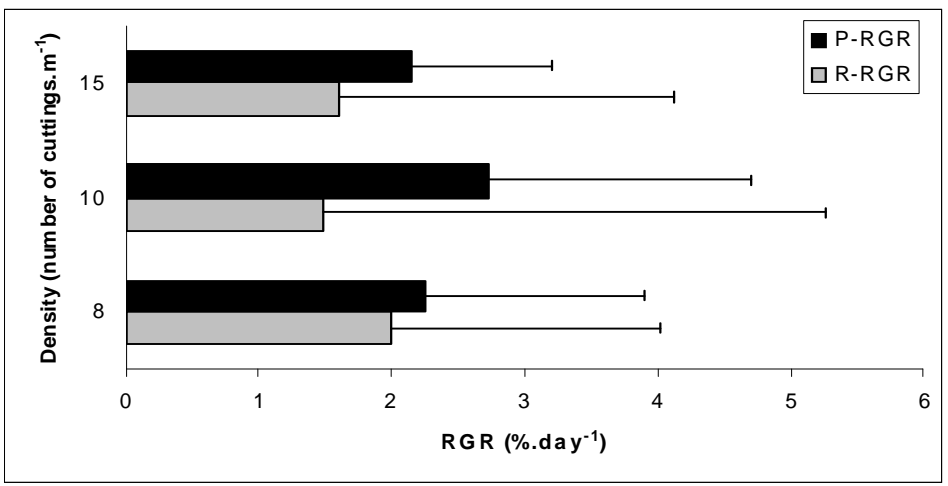

Figure 4 - Average RGR $\left(\% \cdot\right.$ day $\left.^{-1}\right)$ for $G$. domingensis cultivated in net cages comparing three cuttings densities (8, 10 and 15 cuttings/rope), accomplished in June 2003 (where: PRGR = Potential Relative Growth Rate; R-RGR = Real Relative Growth Rate; $n=3$; bars $=$ st. dev.).

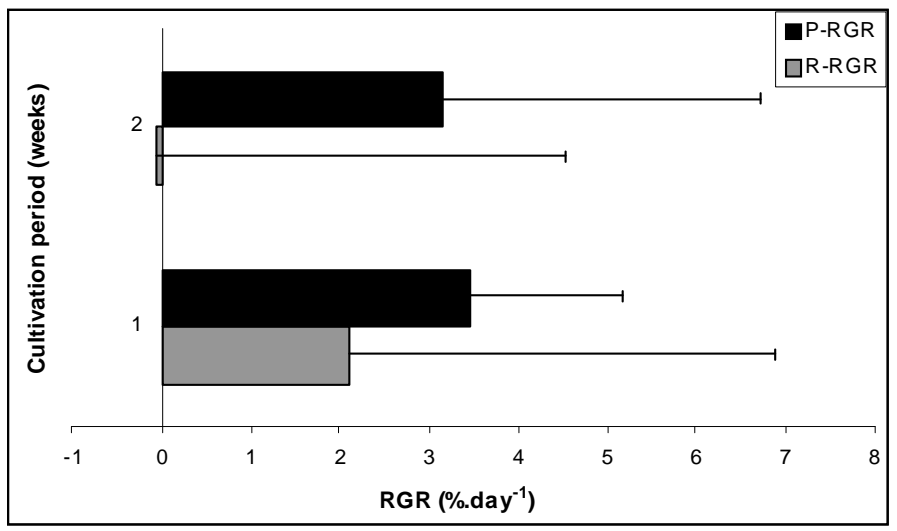

Figure 5 - Average RGR (\%.day ${ }^{-1}$ ) for $G$. domingensis cultivated in net cages comparing two cultivation periods (one and two-weeks) accomplished in July 2003 (where: P-RGR = Potential Relative Growth Rate; R-RGR = Real Relative Growth Rate; $n=3$; bars = st. dev.).

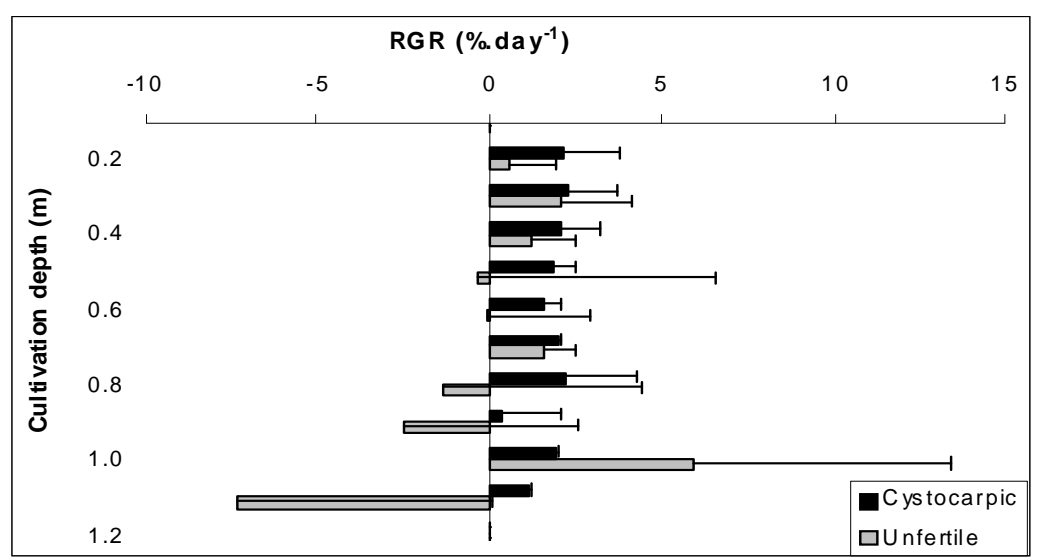

Figure 6 - Average R-RGR $\left(\% \cdot\right.$ day $\left.^{-1}\right)$ for $G$. domingensis cultivated in net cages comparing cystocarpic and unfertile plants, accomplished in June 2003 (density $=10$ cuttings/rope; $\mathrm{n}=3$; bars $=$ st. dev.). 


\section{DISCUSSION}

Among the environmental factbors recorded during the experiments, winds from the Southern quadrant that were intense during the winter could be the major local climatic factor limiting the growth and handling. An alternative to be tested to reduce the losses during such situations would be increasing the depth. Despite that $G$. domingensis cultivation during the winter could be convenient and strategic considering the possibility to use the idle work force and the structure of mussel farms. During this period, the water was more turbid and it could inhibit the epiphytic development. Glenn et al. (1996) reported best results with $G$. parvispora in Hawaii also during the winter, which supported the present hypothesis and choice.

The herbivory is the major limiting factor worldwide (Oliveira et al., 2000). The present results in the experiments without cages suggested that herbivory in the cultivation area might be high and the cultivation would be feasible only if protected by the nets. The present experimental design was not planned to test the herbivory, but to approach a feasible way to cultivate $G$. domingensis.

The relatively good performance of $G$. domingensis in net cages in low depths could be influenced by the high number of epiphytes. Although the competition for light with the cultivated plants, the epiphytes acted as an alternative food source for small grazers that certainly continued feeding inside the cages. Corroborating such hypothesis, Anderson et al. (1998) observed that certain mesograzer species presented feeding preference for a traditional epiphyte, Ceramium diaphanum, over G. gracilis, an agarophyte commercially cultivated in South Africa. This mesograzer activity was also evaluated by Smit et al. (2003), who reported that when grazers, mainly isopods, were present in low numbers, they fed preferably on epiphytic macroalgae, and the effect could be beneficial to the cultivated species. On the other hand, when the number of isopods increase and most epiphytes sources are consumed they feed on the cultivated plants, decreasing seaweed growth and production. Considering that epiphytes compete for light, nutrients, inorganic carbon, and also have allelopathic defenses (Littler and Littler, 1984), and the mesograzers are strong consumers that can cause serious production losses, future studies are recommended to find out a way to biologically control them. Fish, for example, could be a potential biocontroller for Gracilaria cultures (Friedlander et al., 1996).

The tie-tie method is extensively used in the culture of seaweed, especially eucheumatoid species, and, according to Ask and Azanza (2002), it has some important advantages such as simplicity, use of inexpensive and readily available material, and good plant growth. However, there is a need to replace the "tie-tie" system with a less labor-intensive method as well as an increase in efficiency in handling, planting, maintaining and harvesting. The insertion method is cheaper and the handling is shorter, but it is not recommended due to high losses, reduced potential and real RGR, and consequent lower productivity. However, in the present study, the tie-tie attachment method presented better results than the insertion method. Nevertheless, future studies should consider longer experimental periods in order to compare the two methods under longer periods of culture. Furthermore, new attachment methods should be tested, considering the culture environment. It is noteworthy that new farm systems intended for family farmers should be simpler and with a low capital and operating costs (Ask and Azanza, 2002).

Damaging effects of excessive light have been shown for Eucheuma. However, Ask and Azanza (2002) reported that it could be offset by decreasing the distances between the lines and cuttings attached to lines. Also, a high density could decrease epiphytism and the negative effects of high hydrodinamics events. Study did not find significant differences among the three tested cuttings densities. However the same densities should be tested under longer periods of culture, since the relatively short period of culture in the present study might have not allowed enough time for powerful comparisons among the cuttings densities.

The two cultivation periods evaluated here did not present significant differences despite the fact that first week had presented positive RTR and the second week slightly negative. Further studies should investigate whether it was due to punctual environmental conditions or due to the factors related to some physiological conditions of the plants.

Although the differences between the cystocarpic 
and unfertile specimens were not significant, Guimarães et al. (1999), who evaluated the in vitro development of $G$. domingensis, observed higher RGR in unfertile thalli than in cystocarpic ones. However, the large variances observed for unfertile plants might be related to the possible presence of misidentified gametophytic and sporophytic plants, due to the absence of reproductive cells or structures. Some authors have demonstrated different colloid characteristics according to reproductive status. The spore cultivation techniques could represent a way to select this reproductive status in order to achieve high RGR and desirable colloid characteristics.

Future studies should evaluate the costeffectiveness of a commercial $G$. domingensis production in net cages and the likely water quality improvements within and around mussel farms areas. Additionally, among other important issues still to be addressed for the studied area are possible seasonal RGR variations; yield and quality of agar according to the cultivation systems; and potential negative and positive impacts on the biological community.

\section{ACKNOWLEDGMENTS}

The authors thank the Laboratório de Moluscos Marinhos at the Federal University of Santa Catarina, for providing the required structures and Coordenação de Aperfeiçoamento de Pessoal de Nível Superior - CAPES and Conselho Nacional de Desenvolvimento Científico e Tecnológico CNPq for scholarships.

\section{RESUMO}

A aqüicultura de animais pode afetar negativamente $\mathrm{o}$ ambiente pelo aumento de nutrientes orgânicos na água. As macroalgas, como filtro de nutrientes solúveis, especialmente nitrogênio e fósforo, pode ser uma estratégia para reduzir este impacto. Neste estudo apresentamos os resultados obtidos com o cultivo vertical de Gracilaria domingensis em uma área de cultivo de moluscos na praia do Sambaqui, Florianópolis, Santa Catarina, Brasil. A taxa de crescimento relativo foi utilizada como parâmetro para avaliar: o método para prender as mudas às cordas de cultivo; a densidade algal; o tempo de cultivo, o desempenho de plantas cistocárpicas e plantas não férteis; e a herbivoria. Os resultados indicaram alta taxa de herbivoria e o cultivo se mostrou viável apenas com a proteção de telas. Os melhores resultados foram obtidos com o método tie-tie e com densidade inicial de 15 mudas por metro de corda de cultivo. O tempo de cultivo indicado para o sistema proposto é de no máximo uma semana de cultura no mar. As diferenças entre plantas cistocárpicas e não férteis não foram significativas. Os próximos estudos devem enfocar o custobenefício de produzir macroalgas em gaiolas e seus benefícios para a qualidade da água nas áreas de cultivo de moluscos.

\section{REFERENCES}

Anderson, B.C.; Smit, A.J. and Bolton, J.J. (1998), Differential grazing effects by isopods on Gracilaria gracilis and epiphytic Ceramium diaphanum in suspended raft culture. Aquaculture, 169, 99-109.

Ask, E.I. and Azanza, R.V. (2002), Advances in cultivation technology of commercial eucheumatoid species: a review with suggestions for future research. Aquaculture, 206, 257- 277.

Bainy, A.C.D.; Almeida, E.A.; Muller, I.C.; Ventura, E.C. and Medeiros, I.D. (2000), Biochemical responses in farmed mussel Perna perna transplanted to contaminated sites on Santa Catarina Island, SC, Brazil. Marine Environmental Research, 50, 411-416.

Buschmann, A.H.; Briganti, F. and Retamales, C.A. (1997), Intertidal cultivation of Gracilaria chilensis (Rhodophyta) in southern Chile: long term invertebrate abundance patterns. Aquaculture, 156, 269-278.

Dawes, C.J. (1998). Marine Botany. $2^{\text {nd }}$ ed. John Wiley and Sons, New York, $480 \mathrm{p}$.

Friedlander, M.N.; Weintraub, A.; Freedman, J.; Sheer, Z.; Snovsky, J.S. and Kissil, G.W. (1996), Fish as potential biocontrollers of Gracilaria (Rhodophyta) culture. Aquaculture, 145, 113-118.

Glenn, E.P.; Moore, D.; Fitzsimmons, K. and Azevedo, C. (1996), Spore culture of the edible red seaweed, Gracilaria parvispora (Rhodophyta). Aquaculture, 142, 59-74.

Glenn, E.P.; Moore, D.; Akutagawa, M.; Himler, A.; Walsh, T. and Nelson, S.G. (1999), Correlation between Gracilaria parvispora (Rhodophyta) biomass production and water quality factors on a tropical reef in Hawaii. Aquaculture, 178, 323-331.

Guimarães, M.; Plastino, E.M and Oliveira, E.C. (1999), The life history, reproduction and growth of Gracilaria domingensis (Gracilariales, Rhodophyta) from Brazil. Botanica Marina, 42, 481-486. 
Littler M.M. and Litler D.S. (1984), Models of tropical reef biogenesis: The contribution of algae. In Progress in Phycological Research, ed. F. E. Round. V. J. Chapman, London: Biopress, 3, 323 - 364.

Marinho-Soriano, E.and Bourret, E. (2003), Effects of season on the yield and quality of agar from Gracilaria species (Gracilariaceae, Rhodophyta). Bioresource Technology, 90, 329-333.

Norziah, M.H. and Ching, C.Y. (2000), Nutritional composition of edible seaweed Gracilaria changgi. Food Chemistry, 68, 69-76.

Oliveira, E.C and Miranda, G.E.C. (1998), Aspectos sociais e econômicos da explotação de algas marinhas do Brasil. In: Annais do IV Congresso Latino Americano, II Reunião Libero-Americana e VII Reunião Brasileira de Ficologia. E.J. de Paula and outros (eds.). 149-156pp.

Oliveira, E.C., Alveal, K. and Anderson, R.J. (2000), Mariculture of the agar-producing gracilarioid red algae. Reviews in Fisheries Science, 8, 345-377.
Smit, A.J.; Fourie, A.M.; Robertson, B.L. and du Preez, R. (2003), Control of the herbivorous isopod, Paridotea reticulata, in Gracilaria gracilis tank cultures. Aquaculture, 217, 385-393.

Troell, M.; Halling, C.; Nilsson, A.; Buschmann, A.H.; Kautsky, N. and Kautsky, L. (1997), Integrated marine cultivation of Gracilaria chilensis (Gracilariales, Rhodophyta) and salmon cages for reduced environmental impact and increased economic output. Aquaculture, 156, 45-61

Yoshimura, C.Y. (2006), Avaliação do potencial de cultivo e produção de ágar de Gracilaria domingensis e de Gracilaria caudata (Rhodophyta, Gracilariales) na Enseada de Armação do Itapocoroy (Penha, Santa Catarina). Tese de doutorado. Universidade de São Paulo, USP, Brasil.

Received: November 20, 2006 Revised: November 30, 2007; Accepted: January 15, 2010 